\title{
Event Schemas and Thematic Roles in Ilami Dialect of Kurdish
}

\author{
Shahla Sharifi \\ Associate professor in linguistics, Ferdowsi University of Mashhad, Iran \\ E-mail: sh-sharifi@um.ac.ir \\ Amir Karimipour (Corresponding author) \\ MA student in Linguistics, Ferdowsi University of Mashhad, Iran \\ E-mail:am_ka439@stu-mail.um.ac.ir
}

Received: September 3, 2012 Accepted: October 8, 2012 Published: December 1, 2012

doi:10.5296/ijl.v4i4.2336 URL: http://dx.doi.org/10.5296/ijl.v4i4.2336

\begin{abstract}
Speakers use schemas to organize their knowledge of the world. Without these mental structures, communication would be too difficult, if not impossible. Schemas are of different kinds and event schemas are considered as one of the most important categories of schema. In this paper, we aim to study different kinds of event schemas like, "being schema", "doing schema", "moving schema", etc. in Ilami Kurdish. Our analysis is mainly based on the Dirven \& Verspoor classification. In order to analyze these components, we will cite Kurdish examples, and then we try to analyze these instances by determining main thematic roles of each category. We will also discuss how these roles are affected by or affect something, in an event schema. Results show that Ilami more or less uses the categories previously studied in English.
\end{abstract}

Keywords: Cognitive linguistics, Schema, Event schema, Kurdish 


\section{Introduction}

Cognitive Linguistics (CL) is an approach to the study of language informed by both linguistics and psychology. It describes how language interfaces with cognition, and how it adapts in the course of language usage, phylogenetically in language evolution, ontogenetically in language acquisition, and moment-to-moment in situated, on-line language processing and performance. (Robinson \& Eliss, 2008:2)

Over the past 25 years, Cognitive Linguistics has matured into one of the most prominent alternatives to the linguistics paradigm of Chomskyan generative grammar. Cognitive linguistics as such is no single theory but is probably best seen as a family of approaches which share several theoretical and methodological assumptions. (Robinson \& Eliss, 2008:408)

A semantic theory, part of cognitive grammar, identifies meaning with conceptualization-the structures and processes which are part of mental experience. A central notion is how a conceptual content is construed: the construal of a lexical item depends on several factors, including the cognitive domains in which it appears (e.g. space, time, color) and variations in perspective and salience. (Crystal, 2003: 80)

Schemata, as an important topic in cognitive linguistics, are said to be higher-level complex (and even conventional or habitual) knowledge structures (van Dijk, 1981: 141), which function as ideational scaffolding (Anderson, 1977) in the organization and interpretation of experience. In the strong view, schemata are considered to be deterministic, to predispose the experiencer to interpret his experience in a fixed way. We can think of racial prejudice, for example, as the manifestation of some fixed way of thinking about newly encountered individuals who are assigned undesirable attributes and motives on the basis of an existing schema for members of the race. (Brown, 1989: 247)

For some obvious differences, we can readily modify the details of a cultural schema. For many other subtle differences, however, we often do not recognize that there may be a misinterpretation based on different schemata. In one reported example, an Australian factory supervisor clearly assumed that other factory workers would know that Easter was close and hence they would all have a holiday. He asked another worker, originally from Vietnam, about her plans; the Vietnamese worker immediately interpreted the utterance in terms of being laid off (rather than having a holiday). Something good in person's schema can sound like something bad in another's. (Yule, 1947:87)

Schema is an important topic discussed and studied by many scholars. Gibbs \& Colston (1995) discuss some of the empirical evidence from psycholinguistics, cognitive psychology, and developmental psychology that is consistent with the idea that image schemas and their transformations play important roles in human cognition. Their review suggests possible ways of integrating this research with the findings on linguistic structure and meaning in cognitive semantics. Clausner \& Croft (1997) examine a fifth theoretical construct, that of "image schemas" (recurring basic conceptual structures), and argue that image schemas are a subtype of domain. They argue that it is concepts in domains that are locational or 
configurational, not the domains themselves. They finally analyze image schemas and show how they function like domains, in which are found both locational and configurational concepts. Corbett and Hmieleski (2007) examine the interplay and divergence between the role schema of individuals in corporations and the event schemas necessary to launch a new venture. Then they show how the corporate context can create tension between corporate entrepreneurs' role schemas and the event schemas necessary for entrepreneurship. Ferreti et al (2001) use an integrative account of the processing of words, thematic roles and schema, and then they conclude that this type of detailed world knowledge is tied tightly to on-line thematic roles assignment. Tseng (2007) studies image schemas by drawing on insights not only from cognitive linguistics but also from critical linguistics; he pays special attention to image-schematic pattern in two Chinese Zen poems.

In this article we aim to study different components of event schema in Ilami and specify Theta roles according to a pattern, previously discussed by Dirven and Verspoor (2004). In order to achieve this goal, we will present sufficient examples for different event schemas including being schema, happening schema, doing schema, experiencing schema, having schema, moving and transferring schema. These terms will be briefly defined below:

\subsection{The Being Schema}

The main function of the being schema is to relate a characteristic or any other conceptual category to a given entity which does not really play a dominant role in the relationship.

\subsection{The Happening Schema}

The happening schema emphasizes a process that is taking place and the participating entity involved in it. However, the participating entity itself need not really be actively involved in the process and is therefore also a patient.

\subsection{The Doing Schema}

In a doing schema one entity is seen as the source of the energy that is developed, and consequently as instigating the action. It should be noted that doing schema is almost exclusively linked to human agents.

\subsection{The Experiencing Schema}

By experiencing schema we mean the mental processing of the contact with the world. This is expressed by mental verbs such as to see, to feel, to know, to think, to want etc. the entity involved in an "experiencing" schema is neither passive like a patient nor active like an agent. This role is called the Experiencer, the role of the entity that has a mental experience.

\subsection{The Having Schema}

In most prototypical case, the having schema relates a human possessor to the object possessed, but it may also relate an affected entity to its cause of affection, a whole to its parts, or one family member to another. (Dirven \& Verspoor, 2004) 


\subsection{The Moving Schema}

In addition to the patient, the moving schema has three other roles that specify the movement. When something moves, it has a place where the movement begins, the source; a place where the movement ends, the goal; and a way of getting from the one to the other, the path.

\subsection{The Transferring Schema}

Another common schema combines moving and doing schemas, but in this case there is a second animate participant, the recipient, which functions as the goal for the patient. The source is also animate. This is called the transferring schema.

\subsection{An Introduction to Kurdish}

Kurdish has many dialects, and Ilami dialect is one of these varieties. Britannica describes Kurdish so:

Kurdish is a new western Iranian language spoken in Kurdistan; it ranks as the third largest Iranian language group, after Persian and Pashto, and has numerous dialects. There are two main dialect groups. The northern group-spoken from Mosul, Iraq, into the Caucasus - is called Kurmānji; in Turkey, Hawar (Turkized Latin) characters are used in the written form. It is spoken within a broad region that stretches roughly from Orūmīyeh, Iran, to the lower reaches of traditional Kurdistan in Iraq. In Iraq, Kurdī is the official form of Kurdish. Subdialects of Kurdish include Kermanshahī, Lekī, Guran̄̄, and Zaza. (Britannica)

As noted, Ilami (sometimes called Feyli) is another variety under the Kurdish umbrella. This dialect is widely spoken in Ilam, a small mountainous city located at the west of Iran. Ilami shares some similarities with Kermanshahi and Kalhori. While most of Kurdish varieties have ergative system, Ilami does not have such a system. (Kalbassi, 2010).

\section{Data Analysis}

In this section, Kurdish examples will be given and each instance will be analyzed. For more convenience, English literal and exact translations for each instance are given- 
Table 1. The being schema

\begin{tabular}{|l|l|}
\hline Kurdish examples & English translation \\
\hline $\begin{array}{l}\text { mærizəm } \\
\text { sick am }\end{array}$ & I am sick. (attribution) \\
\hline $\begin{array}{l}\text { kawSelæ fəræ ræin bin } \\
\text { shoes the very beautiful were }\end{array}$ & $\begin{array}{l}\text { The shoes were very beautiful. } \\
\text { (Attribution) }\end{array}$ \\
\hline $\begin{array}{l}\text { kətawæ ha banə məzæ } \\
\text { book the is on the table }\end{array}$ & The book is on the table. (Location) \\
\hline $\begin{array}{l}\text { kəræ abi dæ wæræ } \\
\text { bəralzamæ } \\
\text { boy the blue wearing cousin my is }\end{array}$ & $\begin{array}{l}\text { The boy with the blue shirt is my } \\
\text { cousin.(membership and Identifier) }\end{array}$ \\
\hline $\begin{array}{l}\text { qelaqeran köjə mærufegæ ha dæ ilam } \\
\text { Qelaqeran mountain a famous is } \\
\text { (which) is in Ilam }\end{array}$ & $\begin{array}{l}\text { Qela-qeran is a well-known } \\
\text { mountain in Ilam. (location) }\end{array}$ \\
$\begin{array}{l}\text { baxelə xuwe ha eran } \\
\text { Orchars good are (in) Iran }\end{array}$ & $\begin{array}{l}\text { There are fruitful orchards in Iran. } \\
\text { (existential) }\end{array}$ \\
\hline
\end{tabular}

As we can see, there are several kinds of "being-schema" in Kurdish. It can be deduced that all the examples above share a common feature which is "being". mærizəm is a sentence containing an attributive adjective and a form of be:

a) mæriz+om

The next example has another form of verb be as well:

b) kəræ abi da war+a bəralzam $+\mathfrak{x}$

It is clear that the relative clause (abi dæ wær+æ) acts as an identifier, while koræ bəralzam $+æ$ can show a membership (of a family for instance). In other words, a relative clause is embedded into the main sentence to identify the "patient" more clearly.

As we will see, qelaqeran and kətawæ in the following examples are semantically patients and their locations can be inferred from the whole sentences (i.e.in Ilam and on the table).

a) qelaqeran köjə mærufegæ ha dæ ilam

b) kətawæ ha banə məzæ 
Table 2. The happening schema

\begin{tabular}{|c|c|}
\hline Kurdish examples & English translation \\
\hline $\begin{array}{ll}\text { awæ dere rə } \int \mathrm{e} \\
\text { water the is dripping }\end{array}$ & The water is dripping. \\
\hline $\begin{array}{l}\text { qəsæ hæ dæ } \quad \text { wirəmaw } \mathrm{t} \int \mathrm{u} \\
\text { words always from memory go }\end{array}$ & I always forget what $\mathrm{i}$ have said. \\
\hline $\begin{array}{l}\text { dænə bərenđకææ } \mathrm{t} \int \partial g \\
\text { time the rice went }\end{array}$ & The rice is dough-baked. \\
\hline $\begin{array}{l}\text { dæ gærmi agər dæm } \\
\text { from heat fire from me went }\end{array}$ & It is too hot. \\
\hline $\begin{array}{l}\text { 3an pærijæ namə særəm } \\
\text { pain jumped into my head }\end{array}$ & I have a headache. \\
\hline $\begin{array}{l}\text { bimæ gəl } \\
\text { became rolling }\end{array}$ & I fell down. \\
\hline
\end{tabular}

Patients in all the examples mentioned above undergo a process passively.

a ) xagelæ derən kə lən

eggs the are boiling

b) dæ gærmi agər dæm $\quad$ t $\int ə g$

\section{from heat fire from me went}

"xagelæ" and "m" are patients passively involved in some processes. In other words, "xagelæ" (eggs) are involved in the process of boiling and " $\mathbf{m}$ " (me) in the process of perspiration.

Table 3. The doing schema

\begin{tabular}{|c|c|}
\hline Kurdish examples & English translation \\
\hline $\begin{array}{lccc}\text { daləgəm } & \text { qæzaj } & \text { tamdare } & \text { dərəs } \\
\text { kərd } & & & \\
\text { mother } & \text { my } & \text { food } & \text { tasty } \\
\text { made } & & & \end{array}$ & $\begin{array}{l}\text { My mother cooked a delicious } \\
\text { meal. }\end{array}$ \\
\hline $\begin{array}{l}\text { tfæn saæt rə kərdim } \\
\text { severl hours walked we }\end{array}$ & We walked for hours. \\
\hline 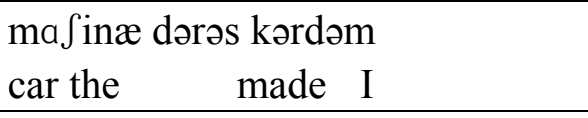 & I repaired the car. \\
\hline $\begin{array}{l}\text { oj had3ætelæ } \quad \text { urt } \\
\text { she dishes the washed }\end{array}$ & She washed the dishes. \\
\hline
\end{tabular}

Unlike the examples mentioned so far, in a doing schema an agent is always present. If we look at these examples, we can see that agents usually do an action: 

a) fəræ dærs
xwænəsəm

a lot lesson studied $\mathrm{i}$

b) əj had3æætelæ $\quad$ urt

she dishes the washed

əm and $\boldsymbol{\partial j}$ in (a) and (b) are considered as agents (referring to I and he/she) who do two different actions and are the source of energy (studying hard and washing the dishes).

Table 4. The experiencing schema

\begin{tabular}{|l|l|}
\hline Kurdish examples & English translation \\
\hline $\begin{array}{l}\text { xwæm Sənæwəsəmæ } \\
\text { myself have heard I }\end{array}$ & I have heard the news . \\
\hline $\begin{array}{l}\text { Jansi jækə dæ ræfiqeləm dim } \\
\text { by chance one of friends my saw I }\end{array}$ & $\begin{array}{l}\text { I saw one of my friends } \\
\text { accidently. }\end{array}$ \\
\hline $\begin{array}{l}\text { bəragæm fəræ xwæ } \int \text { e dæ Jəna dijaj } \\
\text { brother my very like from swim come }\end{array}$ & $\begin{array}{l}\text { My brother likes swimming a } \\
\text { lot. }\end{array}$ \\
\hline $\begin{array}{l}\text { ifəm dæ særzæn hemæ særəm duwæ də kwətaw } \\
\text { say I from headache now head my become two } \\
\text { halves }\end{array}$ & My head aches. \\
\hline $\begin{array}{l}\text { wətəm hade bətijæni karə æram bəkej } \\
\text { said I perhaps could you something for me do }\end{array}$ & $\begin{array}{l}\text { I thought that you may help } \\
\text { me. }\end{array}$ \\
\hline
\end{tabular}

Experiencing schemas differ from doing schemas (in that agents always do an action in a doing schema), because in experiencing schemas, as its name indicates, agents always undergo an experience. Let us analyze some of the examples above to illustrate the fact:

a) Sansi jækə dæ ræfiqeləm dim

by chance one of friends my saw i

b) æli xwe dəzanəs æra məqæsəræ

ali himself knew why blameworthy is he

In (a) and (b), "dijən" (to see) and "zanəsən" (to know) are two experiences. "I" and "Ali" experience two situations without doing actions. It might be worth noting that in Ilami dialect sometimes "wətən" (saying) is used with the meaning of "thinking" or "feeling" as well:

c) wətəm hade bətijæni karə æram bəkej

said I perhaps could you something for me do 
Table 5. The having schema

\begin{tabular}{|l|l|}
\hline Kurdish examples & English translation \\
\hline $\begin{array}{l}\text { adætelə gæne dere } \\
\text { habits bad has he }\end{array}$ & $\begin{array}{l}\text { He has some bad habits. ( mental } \\
\text { possession) }\end{array}$ \\
\hline $\begin{array}{l}\text { dogəlæ bæffæ dere } \\
\text { two children has she }\end{array}$ & $\begin{array}{l}\text { She has two children. (material } \\
\text { possession) }\end{array}$ \\
\hline $\begin{array}{l}\text { fəkrelə xuwe derəm } \\
\text { thoughts good have i }\end{array}$ & $\begin{array}{l}\text { I have good plans in mind. } \\
\text { ( mental possession) }\end{array}$ \\
\hline $\begin{array}{l}\text { dusə da ləge dere } \\
\text { love mother her has she }\end{array}$ & $\begin{array}{l}\text { She loves her mother. ( mental } \\
\text { possession) }\end{array}$ \\
\hline
\end{tabular}

In the having schemas mentioned thus far, agents possess a property or specific feature(s). As it was seen this possession can be either physical or mental.

Although "dogəlæ bæTfæ" (two children) is a material possession, "adætelə gæn”( bad habits) can be considered as a mental possession.

Table 6. The moving schema

\begin{tabular}{|l|l|}
\hline Kurdish examples & English translation \\
\hline $\begin{array}{l}\text { ej hæ dæ mal ta mædræsæ wæ pa } \mathfrak{T} \int \mathrm{u} \\
\text { she from house to school by foot }\end{array}$ & $\begin{array}{l}\text { She walks from the house to the } \\
\text { school }\end{array}$ \\
\hline $\begin{array}{l}\text { dæ sær3an ta } \int \text { uwæki næxæftəmæ } \\
\text { from headache till morning have not } \\
\text { slept I }\end{array}$ & $\begin{array}{l}\text { I had a headache; I could not } \\
\text { sleep until morning }\end{array}$ \\
\hline
\end{tabular}

This kind of schema is always involved by a movement. The following example represents the agent [ej] moving from one place to another. The source, from which the movement starts, is [mal] (house) and the goal is [mædræsæ] (school). It should be noted that this moving schema can take place in the form of time too:

a) dæ sær an ta uwæki næxæftəmæ

from headache till morning have not slept I

ta uwæki: End

In the example above a starting point is not mentioned, but it can be mentioned and the sentence is still acceptable:

b) dæ sær an da dijashaw ta $\int$ uwæki næxæftəmæ

from headache from night till morning have not slept I

dæ dijæ $\int a w:$ Start

ta Suwæki: End 
Table 7. The transferring schema

\begin{tabular}{|l|l|}
\hline Kurdish examples & English translation \\
\hline $\begin{array}{l}\text { bankæ p læ degæman } \\
\text { bank the money give us }\end{array}$ & $\begin{array}{l}\text { The bank will give us the } \\
\text { money. }\end{array}$ \\
\hline $\begin{array}{l}\text { hæqə dæsə xejatæ dam } \\
\text { fee his tailor the paid i }\end{array}$ & I paid the tailor's fee. \\
\hline $\begin{array}{l}\text { kətawæ dæ kətawxanæ qært kərdəgæ } \\
\text { book the from library the } \\
\text { borrowed he }\end{array}$ & $\begin{array}{l}\text { He borrowed the book from the } \\
\text { library. }\end{array}$ \\
\hline
\end{tabular}

In this type of schema, a person always receives something as a receiver. As it can be seen, [xejat] is the receiver of the fee and [mo] is the agent (a person who paid the fee).

a) hæqə dæsə xejatæ dam

fee his tailor the paid $\mathrm{i}$

\section{Conclusion}

In this article we tried to analyze different event schemas in Ilami Kurdish. We saw that the same categorization suggested by Dirven and Verspoor can be justifiable in Kurdish too. In other words, we can find many instances for each category (like being, happening schemas, etc.). It should be noted that small differences are still observable. For example it is not common for a "pain" to jump into "head" or "stomach" in English, but it is widely used in Kurdish. So "pain" can be considered as an agent/doer that does an action and affects someone (patient), except that it is not a human being. It can be said that some of the Kurdish examples are an amalgam of different event schemas and should not be classified in one category exclusively. For example "ej hæ dæ mal ta mædræsæ wæ pa $\mathfrak{T} \int u$ " can be considered as moving and doing schemas. We should not forget that often the meaning of the verbs is no longer understood literally as we saw in some of the happening schemas. "dænə bərenđzæ tfog" has a form of "going" and when it is translated literally, someone may think of it as a doing schema for instance. But it is metaphorically used to refer to a change in shape and taste. In this article some aspects of event schemas were studied and scrutinized. A study of other Kurdish schemas can be of a high value and can be done for the next research.

\section{Reference}

Anderson, R. C. (1977). The notion of schemata and the educational enterprise in (eds.) R. C. Anderson, R. J. Spiro \& W.E. Montague.

Brown, G., \& Yule,G., (1983), Discourse Analysis, Cambridge University.

Clausner, T. C., \& Croft, W. (1997). Productivity and schematicity in metaphors. Cognitive science, 21, 247-282. http://dx.doi.org/10.1207/s15516709cog2103_1 
Corbett, A. C. and Hmieleski, K. M. (2007), The Conflicting Cognitions of Corporate Entrepreneurs. Entrepreneurship Theory and Practice, 31, 103-121. http://dx.doi.org/10.1111/j.1540-6520.2007.00165.x

Crystal, D., (2003). A dictionary of linguistics \& Phonetics, 5ed, Oxford: Blackwell press.

Dirven, R., \& Verspoor, M. (2004). Cognitive exploration of language and linguistics, $2^{\text {nd }}$ ed, JOHN BENJAMINS PUBLISHING COMPANY.

Ferreti, T. R., McRae, K., \& Hatherell, A. (2001). Integrating verbs, situation schemas, and thematic role concepts. Journal of Memory and Language, 44, 516-547. http://dx.doi.org/10.1006/jmla.2000.2728

Gibbs, R., \& Colston, H. (1995). The cognitive psychological reality of image-schemas and their transformations. Cognitive linguistics, 6, 347-378. http://dx.doi.org/10.1515/cogl.1995.6.4.347

Kalbassi, I. (2010). A descriptive dictionary of linguistic varieties in Iran, Institute for Humanities and cultural studies, Tehran.

Kurdish language. (2012). In Encyclopedia Britannica. Retrieved from http://www.britannica.com/EBchecked/topic/325225/Kurdish-language.

Robinson, P., \& Ellis, N. (2008) Handbook of Cognitive Linguistics and Second Language Acquisition. New York: Routledge.

Situation schemas and semantic roles. (2012). Retrieved from http://www.indiana.edu/ hlw/Sentences/schemas.html

Tseng M. U. (2007). Exploring image schemas as a critical concept: Toward a critical-cognitive linguistics account of image-schematic interactions. Journal of literary semantics, 36(2), 135-157. http://dx.doi.org/10.1515/JLS.2007.008

Van Dijik, T. A. (1981). Review of R. O. Freedle (ed.) 1979. Journal of linguistics, 17, 140-8

Yule, G. (2000). Pragmatics, Oxford University Press, Oxford, New York. 